\title{
ANALYSIS OF AREAS INUNDATED BY TSUNAMIS INDUCED BY EARTHQUAKES AND LANDSLIDES IN THE REGION OF CALABRIA, ITALY
}

\author{
FRANCESCA MINNITI, GIANDOMENICO FOTI \& GIUSEPPE BARBARO \\ DICEAM Department, Mediterranea University of Reggio Calabria, Italy
}

\begin{abstract}
Tsunamis are catastrophic events that occur especially in the Pacific or the Indian Ocean, causing violent inundations and destroying entire cities near the coast. They can also occur in the Mediterranean Sea, but their magnitude is smaller than in the Pacific or Indian Oceans; their effects however can be as fatal, because of high coastal exposure and vulnerability. These have been growing in the last few years as a result of increased coastal anthropization. This situation leads to a careful reflection on assessments of tsunami hazard due to earthquakes or landslides and of the consequences of tsunami impacts. The paper discusses these issues through an application along the Calabrian coasts in southern Italy. Our analysis starts from the description of the phenomena that have already taken place in order to assess the risk associated with any tsunami and to manage the consequent risk affected areas. Tsunamis are due to earthquakes or landslides mainly because of the high seismicity of the particular area. Many seismic events took place over time causing the onset of landslides and coastal floods. In particular the most catastrophic were the landslide-induced tsunami in Scilla in 1783, and the tsunami in the Strait of Messina in 1908, both in Calabria. In our case study, the Scilla tsunami has been treated with reference to the reconstruction of the landslide that induced it and the related flood. It is important to interpret the mechanisms of induction and propagation of these phenomena through events that have already occurred. In this way, we can have a complete picture of the risk and management of these phenomena in our territory, essential for human safety. The reconstruction of the event was made using QGIS and MATLAB software. QGIS was used to reconstruct the geometric domain, to interpret bathymetric data provided by the IGM (the Military Geographical Institute) and to map areas with risk of flooding, necessary for the management phase. MATLAB was used to reconstruct landslide geometry and the propagation mechanism.
\end{abstract}

Keywords: landslide, tsunami, coastal flooding, risk analysis, management, inundation.

\section{INTRODUCTION}

In recent years, risk assessment has been playing an increasingly important role in coastal areas planning and management. The observations and the current climate change forecasts (e.g. sea level rise, frequency of intense storms, etc.) show a greater exposure of the coastal areas to risk determinants and, in particular, to erosion and inundation phenomena. In a tsunami event, especially, inundation is devasting [1]-[5] and strictly connected with erosion and urbanization.

The criticality analysis concerns not only the physical processes responsible for erosion phenomena and flood, but also the characteristics of the natural environment, the anthropic environment and the interactions between the two [6]-[23]. The growing urbanization of the coastal areas, mainly linked to the construction of tourist settlements in the territories of greater environmental value, led to an increase in the vulnerability of coastal areas and their consequent exposure to storm, erosion and floods.

The paper analyzes a case study of the 1783 Scilla tsunami event; with the use of the QGIS and Matlab software, the bathymetry and the movement of the landslide generated by the earthquake that resulted in the tsunami have been modeled repeatedly. It was then hypothesized that this event affected the same areas in two different historical periods, in 
1954 and today. This was to enable evaluation of the influence of excessive urbanization and coastal erosion on the risk of flood deriving from an event of such reach. The images of the area in 1954 have been downloaded from the Open Data section of the Calabrian Geoportal (http://geoportale.regione.calabria.it/) in geotiff format. The images of the area today have been provided by QGIS in Bing Map format.

\section{HISTORICAL REVIEW}

The catastrophic seismic sequence of February-March 1783 devastated all central and southern Calabria and caused widespread destruction also in the Strait and in the Messina area (Fig. 1). In less than two months, between 5 February and 28 March 1783, there were five very strong earthquakes and several hundred minor events (Fig. 2). The cumulative picture of the damages is vast and of extraordinary gravity: over 180 inhabited centres were destroyed totally or almost totally; there were about 30,000 dead; the destructive effects on buildings were accompanied by extensive upheavals of the soils and the hydrogeological system [24]-[26].

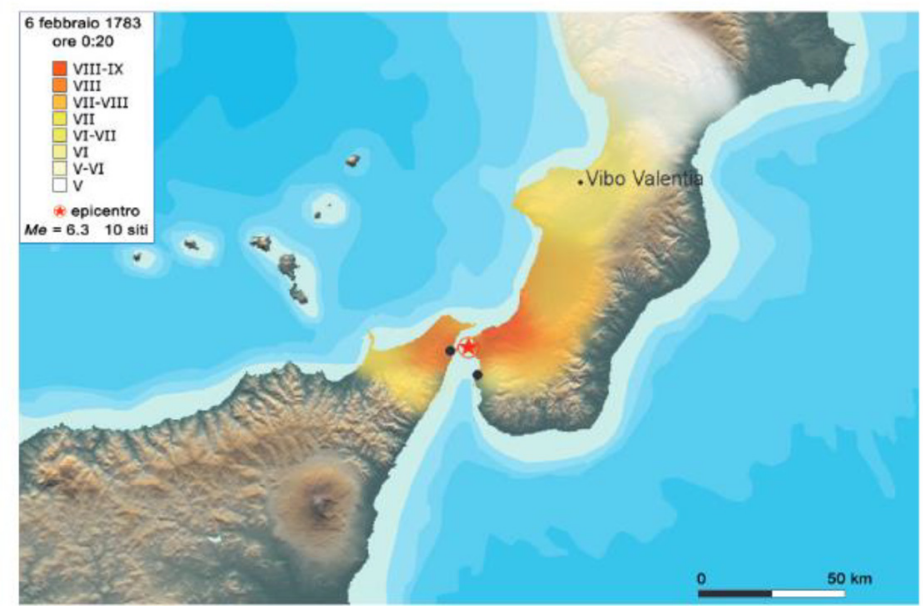

Figure 1: Location of the effects of the earthquake of 6 February 1783. The time is indicated in time universal (UT), which is one hour earlier than the local time [26].

The earthquake of 6 February 1783 was followed in Scilla by a devastating tsunami. Most likely the shock was not directly responsible for the origin of the tsunami, which was instead caused by a large landslide triggered by the earthquake, attested and described by contemporary sources (Fig. 3).

The hilly area of Campallà, located at the south east of Capo Paci' mount, whose soil was already crossed by a large fracture from the previous year, suffered an imposing landslide detachment which involved an area of approximately $2.8 \mathrm{~km}$ wide extended approximately from 0.5 to $1.8 \mathrm{~km}$. The large mass of land precipitated towards the sea, covered the area below cultivated with vineyards, arrived at the beach and partly entered the sea with a front of about $480 \mathrm{~m}$ forming three strips of land from 60 to $100 \mathrm{~m}$ long. Shortly afterwards, three large waves hit the beach of Marina Grande and those of Chianalea and Oliveto, located north 


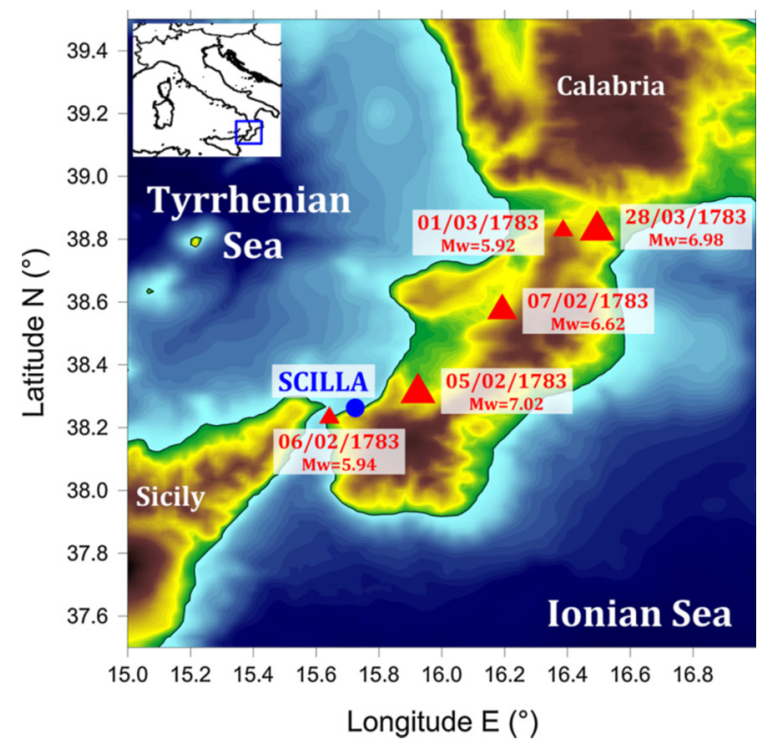

Figure 2: Epicenters (red triangles), dates and magnitudes of the five strongest earthquakes affecting Calabria during the sequence of 1783-1785 [36].

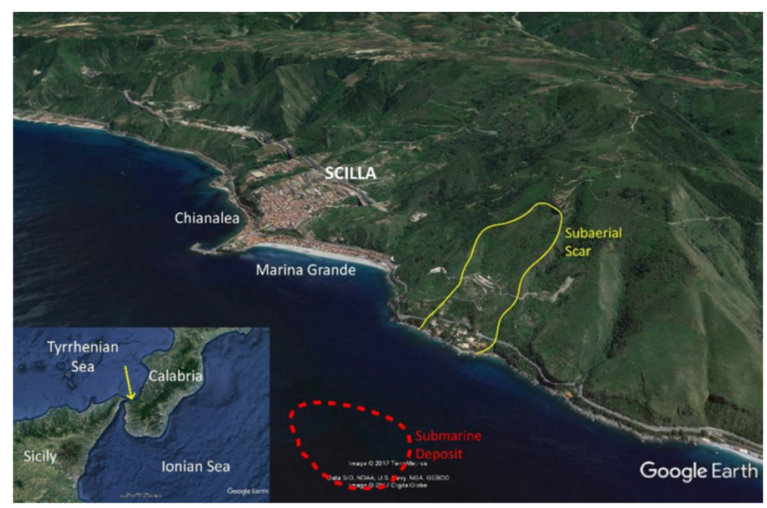

Figure 3: View of Scilla and its surroundings including the two main beaches of Marina Grande and Chianalea (see the position in the map in the bottom left corner). The yellow contour delimits the landslide scar (subaerial) measuring approximately $750 \mathrm{~m} \times 400 \mathrm{~m}$, about $1 \mathrm{~km}$ west of the town. The red contour marks the submarine deposit observed in the geo-marine surveys [38]. (Source: Satellite view obtained by Google Earth [27].)

of the promontory of Scilla, overwhelming most of the population who camped there in boats pulled ashore or in improvised tents, causing about 1,500 deaths. In the Marina Grande, the tsunami reached a height of $6.5 \mathrm{~m}$ in the southern part and $8.5 \mathrm{~m}$ to the north and flooded the beach area for about $200 \mathrm{~m}$ at the outlet of the Livorno torrent. It knocked down over 20 houses and warehouses and the church of the Holy Spirit, located about $35 \mathrm{~m}$ from the beach, 
which had suffered only minor injuries due to earthquakes; it also broke down the doors and caused some damage in the churches of S. Maria delle Grazie and S. Nicola, located respectively about 90 and $100 \mathrm{~m}$ from the sea. The height of the waves was lower, from 4.2 to $3.5 \mathrm{~m}$ on the beaches north of the C. Paci' mount, the Chianalea port, which opened between the houses of the homonymous fishermen's quarter, and the Marina dell'Oliveto at the north end of the country; but even here there were victims. On the Calabrian coast, the tsunami was also remarkable in the Marina di San Gregorio, in Cannitello and Punta Pezzo, south of Scilla (Fig. 4). On the other side, in Sicily, the tsunami mainly hit the village of Torre Faro: a very high wave swept the beach dragging various boats away and causing the death of 26 people. The water hit the beach area from $350 \mathrm{~m}$ to about $1 \mathrm{~km}$ flooding cultivated fields and vineyards [27].

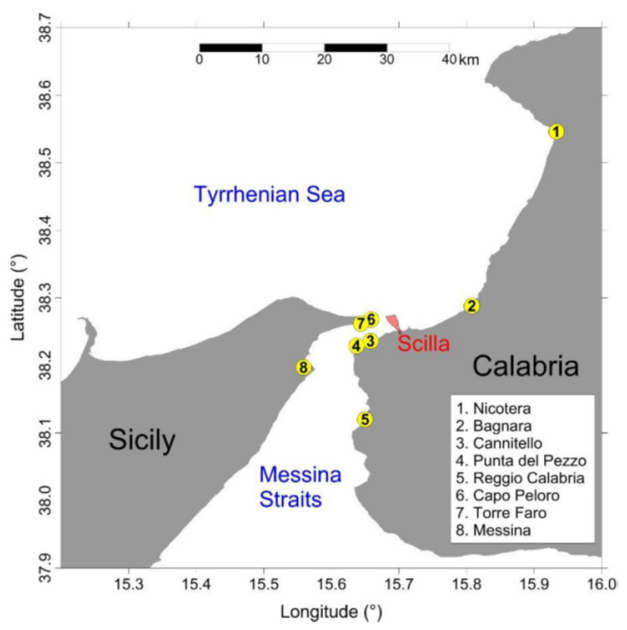

Figure 4: Countries hit by tsunami with epicenter in Scilla [27].

\section{METHODOLOGY}

Risk is a probabilistic concept, it is related with the probability of occurrence of a certain event that can cause harm to people. The notion of risk implies the existence of a source of danger and of the possibility of it causing damage. In this case, the source of the danger and consequent damage is represented by the tsunami event that causes a coastal inundation involving both the buildings and the people. Risk is closely linked to the concept of vulnerability of the coastal areas exposed due to excessive anthropization, which has increased in the past 50 years. The aim of coastal zone management is a correct connection between economic, social and political needs that allow reducing the risk factors as much as possible [28]-[32]. There are two steps to follow in the risk analysis and management of the area considered:

1. Use of data from direct observations;

2. Use of data from existing studies.

In this paper an analysis was made of historical data observed by Minasi [33], [34] and De Lorenzo [35] who recorded both the height of the tsunami waves that hit the beach and the consequent inundation distance. The data obtained from Zaniboni et al. [36] were treated with numerical models to reconstruct the 1783 event: a seismically induced slide and a 
landslide-induced tsunami. The simulation data of run-up height and inundation distance did fit very well with the historical observations in Marina Grande.

\section{EXPERIMENTAL RESULTS AND DISCUSSION}

The modelling of the event was made starting from the reconstruction of the bathymetry of the Strait of Messina, useful for simulating the movement of the landslide in its underwater phase. The bathymetric data were provided by the IGM (the Military Geographic Institute) as unstructured text file in ASCII format. They were then transferred to QGIS to be sorted and georeferenced according to system WGS 84/UTM zone 33N provided by EPGS:32633. The modeling domain consists of the area with bathymetric data and can be seen in Fig. 5 .

To obtain a regular grid of bathymetric values on which to model the movement of the landslide, the data were then processed with Matlab, obtaining a mesh-grid by setting $\Delta x$ and $\Delta y$ equal to $10 \mathrm{~m}$. A grid of extremely detailed values was obtained by choosing a relatively small distance between the nodes (Fig. 6).

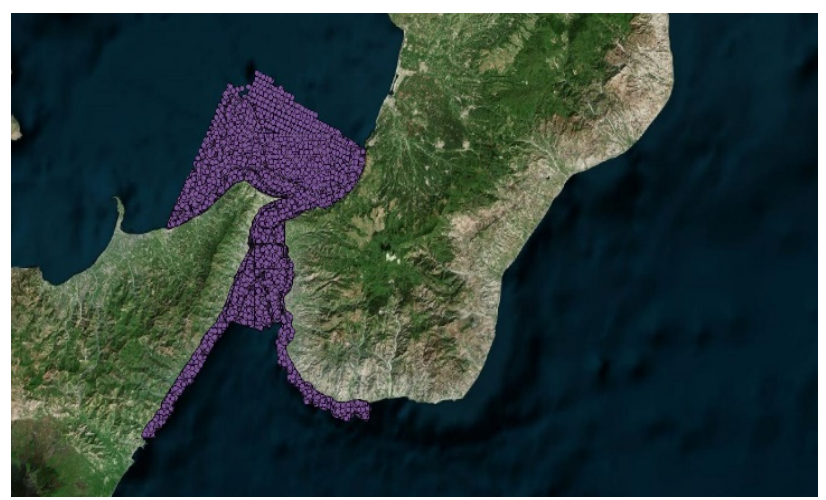

Figure 5: QGIS shapefile whose points represent the georeferenced bathymetric data elaborated by the authors.

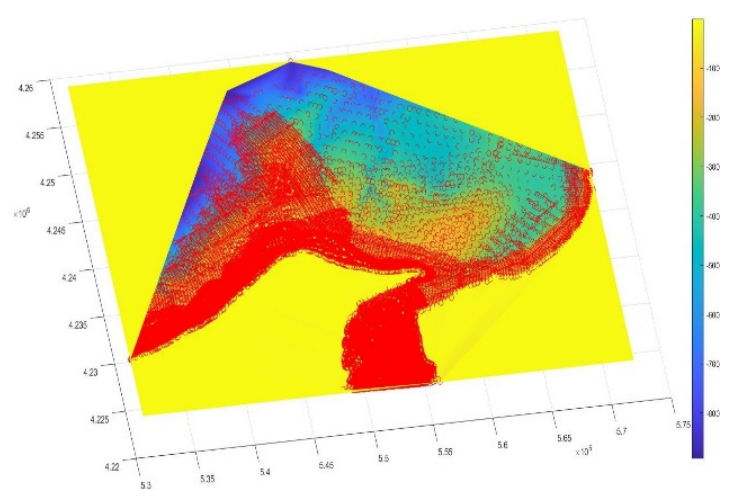

Figure 6: Grid interpolating the bathymetric data highlighted with dots. The color bar represents the bathymetric values. 
Once the domain was generated, a zoom-in was obtained on the part of the domain affected by the landslide to evaluate its shift over time. The domain had dimensions $\mathrm{X}=360 \mathrm{~m}$ (parallel axis to the coast) and $\mathrm{Y}=1,500 \mathrm{~m}$ approximately (orthogonal axis to the coast), which reached a depth of $-300 \mathrm{~m}$ where the landslide had deposited in its final position (Figs 7 and 8) [37], [38].

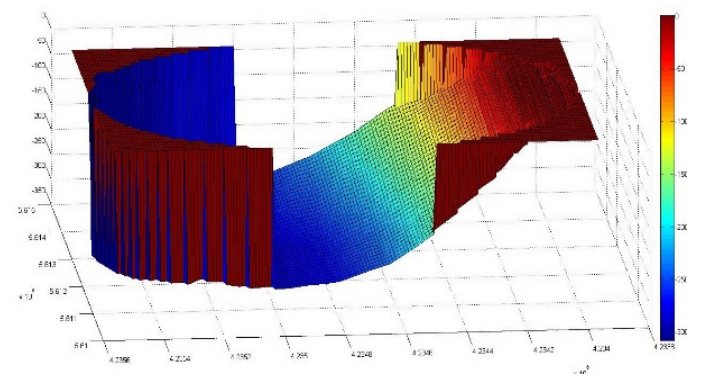

Figure 7: The landslide enters the water 20 seconds after its detachment, the color bar represents the bathymetry, from 0 to -300 b.s.l.

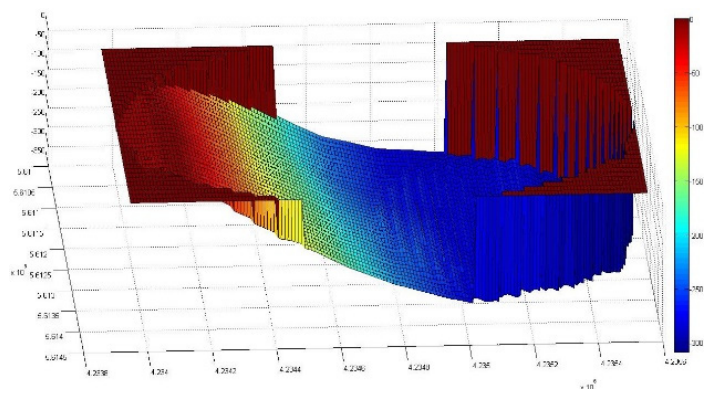

Figure 8: The landslide settles in its final position at a depth of $-300 \mathrm{~m}$ b.s.l.; the color bar represents the bathymetry, from 0 to -300 b.s.l.

The modeling was followed by the evaluation of the inundated areas by the tsunami, assuming two possible different scenarios for the same event:

- $\quad$ Effects of the event as in 1954;

- Effects of the event nowadays.

The analysis, in fact, concerns the possible effects of a devasting natural hazard like a tsunami on the coasts taking into account the urbanization factor. This has tripled since 1950 and with it also the effects of an event of this magnitude in the same area. The images of the area in 1954 were obtained from the Open Data section of the Calabrian Geoportal (http://geoportale.regione.calabria.it/) in the geotiff format. The images of the area as of today were provided with QGIS in the Bing Map format. For the comparison between the two hypothetical scenarios, a cartography of 1954 was used because more dated cartographies are not available as open source. 


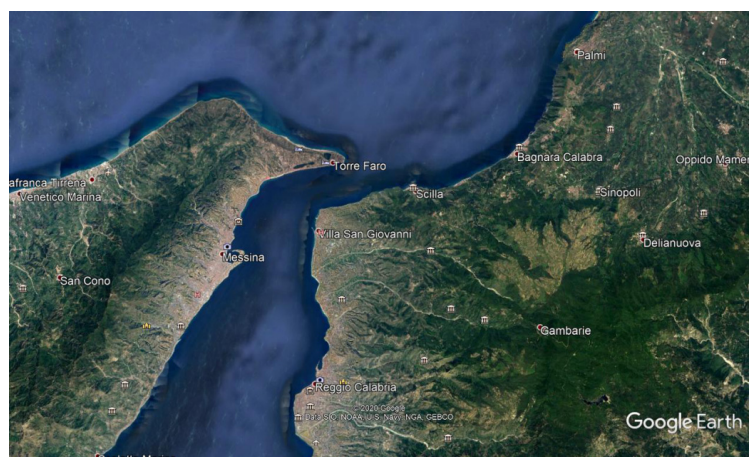

Figure 9: Location of the areas with values of historical data: Scilla, Cannitello (Villa San Giovanni), Reggio Calabria. Satellite view obtained by Google Earth.

The comparison between the inundated areas in 1954 and nowadays has been made using the QGIS software. In such a way, locations were considered whose inundation values came from historical data by Minasi and De Lorenzo (Fig. 9).

As can be seen from the images in Figs 10-15, the same tsunami event, and therefore the same inundation, would have quite different effects in the two cases although quantitatively the flood is the same. Today the effects due to coastal anthropization would be much more devastating and would clog many more buildings and infrastructures that are immediately close to the coast. In Marina Grande and Chianalea, the presence of buildings and commercial activities near the coast has tripled significantly, bringing with it also a major increase of the risk both for the buildings and, above all, the loss of human lives in the face of an event of magnitude similar to that of 1783. Even in Cannitello (Villa San Giovanni) and Reggio Calabria the conditions are very similar to those of Scilla.

As can be seen from the comparison between two respective images (i.e. Figs 10 and 11, Figs 12 and 13, and Figs 14 and 15), the problem of coastal erosion has led from 1950 to today to reducing the portion of the beach by more than half, thus exposing even more the inhabited areas near the coast to devastating inundation. In Cannitello, the beach was reduced

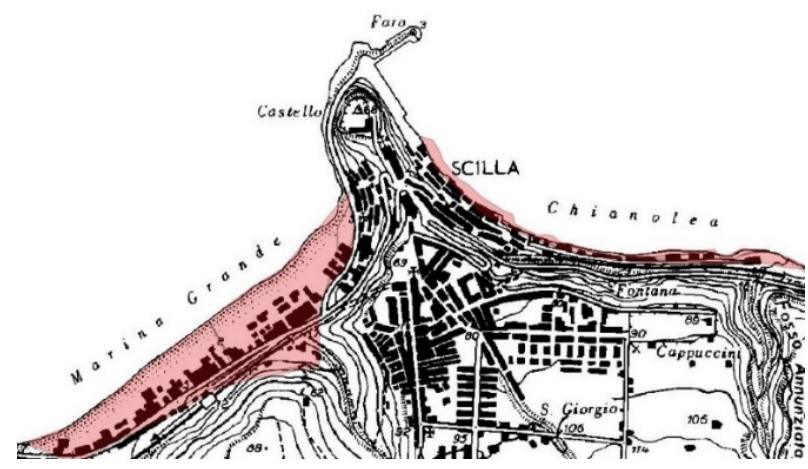

Figure 10: Inundation hypothesis in pink of $200 \mathrm{~m}$ near Livorno river and of $90 \mathrm{~m}$ along S. Nicola's Church in Marina Grande and of $10 \mathrm{~m}$ in Chianalea. (Source: Calabrian Geoportal, 1954.) 


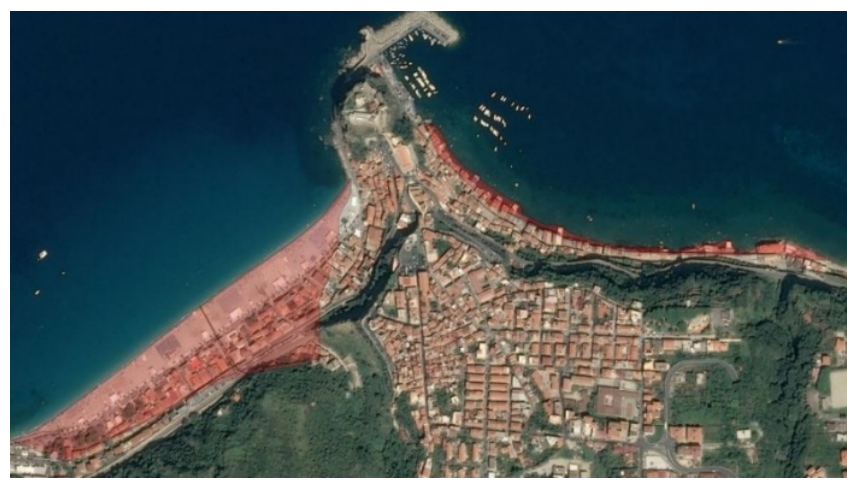

Figure 11: Inundation hypothesis in pink of $200 \mathrm{~m}$ near Livorno river and of $90 \mathrm{~m}$ along S. Nicola's Church in Marina Grande and of $10 \mathrm{~m}$ in Chianalea. (Source: Bing Maps.)

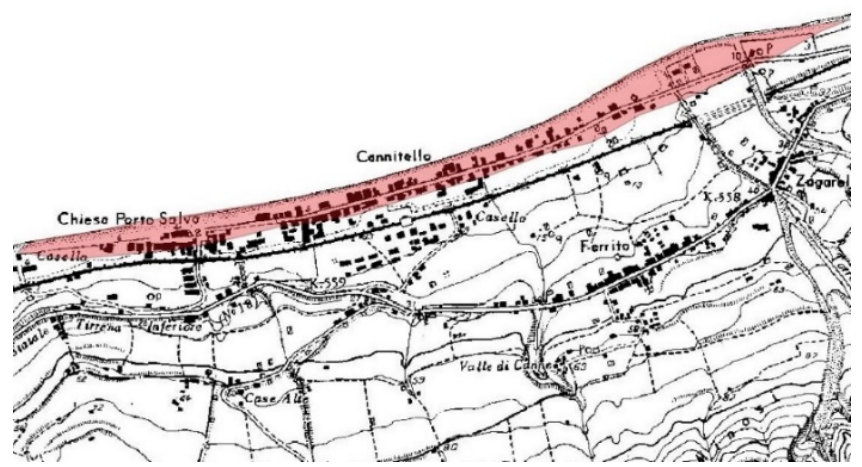

Figure 12: Inundation hypothesis in pink of $50 \mathrm{~m}$ in Cannitello (Villa San Giovanni). (Source: Calabrian Geoportal, 1954.)

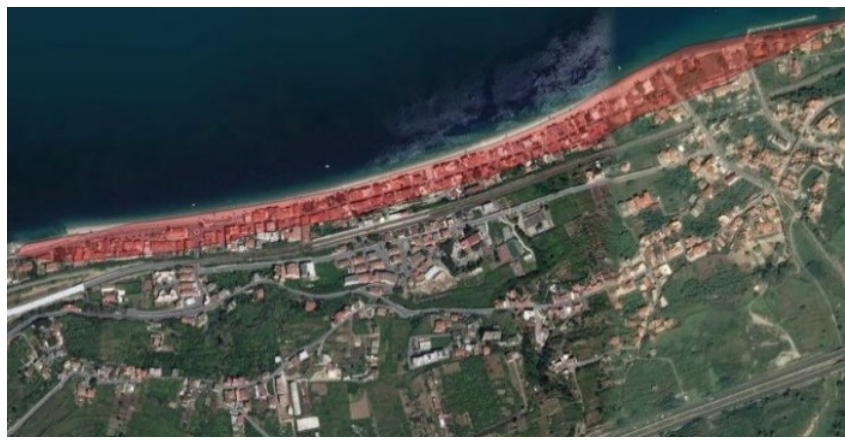

Figure 13: Inundation hypothesis in pink of $50 \mathrm{~m}$ in Cannitello (Villa San Giovanni). (Source: Bing Maps.) 


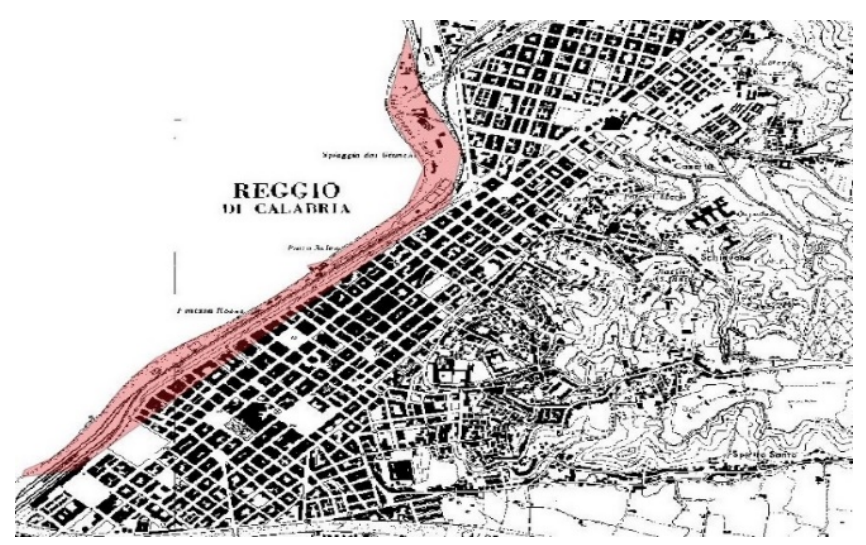

Figure 14: Inundation hypothesis in pink of $80 \mathrm{~m}$ in Reggio Calabria. (Source: Calabrian Geoportal, 1954.)

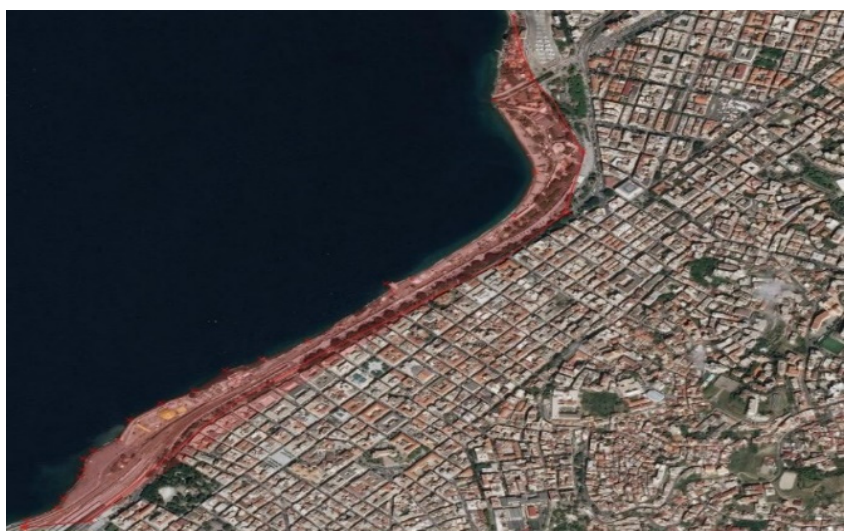

Figure 15: Inundation hypothesis in pink of $80 \mathrm{~m}$ in Reggio Calabria. (Source: Bing Maps.)

from a width of $55 \mathrm{~m}$ to $25 \mathrm{~m}$, in Marina Grande from a width of $95 \mathrm{~m}$ to $60 \mathrm{~m}$, in Chianalea the beach had a width of $15 \mathrm{~m}$ in 1954 and nowadays there is no beach, finally in Reggio Calabria the reduction was from $60 \mathrm{~m}$ to $30 \mathrm{~m}$. There is a very close correspondence between the coastal phenomena that contribute to the balance of the coastal area itself, and the time when this balance is broken by man who constantly pushes towards the urbanization of these areas, the danger and risk grow exponentially.

A good risk management starts from the ability to restore the natural balance of the phenomena affecting the coast, for example the interaction between rivers and the sea. It allows a transport of sediments which counteracts coastal erosion; and then counteracts the excessive anthropization of coastal areas by means of strict policies of compliance with building and environmental standards.

\section{CONCLUSIONS}

Possible effects were analysed in terms of inundation of the tsunami event that occurred in 1873, taking into consideration the same areas inundated during the event itself. The event 
was initially modelled, starting from the reconstruction of the bathymetry using the QGIS software for which the data provided by the IGM (the Military Geographic Institute) were used. The bathymetric data were then transformed through Matlab into a regular grid values with nodes of $10 \mathrm{~m}$ along both the $\mathrm{X}$ axis and the $\mathrm{Y}$ axis. Once the bathymetry was obtained, the movement of the landslide was modelled in its underwater phase, starting from the shore up to a depth of $300 \mathrm{~m}$ where it was deposited and is currently located.

It was then hypothesized that this event had occurred in the same areas in two historical periods, in 1954 and nowadays to evaluate the effects of the inundation in different conditions both from the point of view of anthropization and coastal erosion.

We have seen how these two factors have strongly influenced the different impact that the event would have had in those areas; for a good risk management of tsunamis, it is necessary to improve these two conditions; the reduction of anthropization in coastal areas and a project to reduce coastal erosion on the Calabrian coasts.

\section{REFERENCES}

[1] Percival, S. \& Teeuw, R., A methodology for urban micro-scale coastal flood vulnerability and risk assessment and mapping. Natural Hazards, 97, pp. 355-377, 2019.

[2] Miduri, M., Foti, G. \& Puntorieri, P., Impact generated by Marina of Badolato (Italy) on adjacent coast. Proceeding of 13th International Congress on Coastal and Marine Sciences, Engineering, Management and Conservation MEDCOAST, Mellieha, Malta, 2, pp. 935-945, 2017.

[3] Tinti, S. \& Guidoboni, E., Revision of the tsunami occurred in 1783 in Calabria and Sicily (Italy). Sci Tsunami Hazards, 6, pp. 17-22, 1988.

[4] Tinti, S. \& Tonini, R., The UBO-TSUFD tsunami inundation model: validation and application to a tsunami case study focused on the city of Catania, Italy. Natural Hazards and Earth System Sciences, 13, pp. 1795-1816, 2013.

[5] Schambach, L., Grilli, S.T., Tappin, D.R., Gangemi, M.D. \& Barbaro, G., New simulations and understanding of the 1908 Messina tsunami for a dual seismic and deep submarine mass failure source. Marine Geology, 421, 106093, 2020.

[6] Barbaro, G., Foti, G. \& Malara, G., Set-up due to random waves: influence of the directional spectrum. Proceedings of the 30th International Conference on Ocean, Offshore and Artic Engineering OMAE, Rotterdam, The Netherlands, 6, pp. 789-797, 2011.

[7] Barbaro, G., Foti, G. \& Malara, G., Set-up due to random waves: Influence of the directional spectrum. International Journal of Maritime Engineering, 155, pp. A105A115, 2013.

[8] Barbaro, G., Foti, G., Sicilia, C.L. \& Malara, G., A formula for the calculation of the longshore sediment transport including spectral effects. Journal of Coastal Research, 30, pp. 961-966, 2014.

[9] Tomasicchio, G.R., D’Alessandro, F., Barbaro, G., Musci, E. \& De Giosa, T.M., Longshore transport at shingle beaches: An independent verification of the general model. Coastal Engineering, 104, pp. 69-75, 2015.

[10] Barbaro, G., A new expression for the direct calculation of the maximum wave force on vertical cylinders. Ocean Engineering, 34, pp. 1706-1710, 2007.

[11] Romolo, A., Malara, G., Barbaro, G. \& Arena, F., An analytical approach for the calculation of random wave forces on submerged tunnels. Applied Ocean Research, 31(1), pp. 31-36, 2009. 
[12] Barbaro, G., Saline Joniche: A predicted disaster. Disaster Advances, 6(7), pp. 1-3, 2013.

[13] Scionti, F., Miguez, M.G., Barbaro, G., De Sousa, M.M., Foti, G. \& Canale, C., An integrated methodology for urban flood risk mitigation: the case study of Cittanova (Italy). Journal of Water Resources Planning and Management, 144(10), 05018013, 2018.

[14] Barbaro, G., Petrucci, O., Canale, C., Foti, G., Mancuso, P. \& Puntorieri, P., Contemporaneity of floods and storms: A case study of Metropolitan Area of Reggio Calabria in Southern Italy. Proceedings of New Metropolitan Perspectives (NMP), Reggio Calabria, Italy, 101, pp. 614-620, 2019.

[15] Barbaro, G., Master plan of solutions to mitigate the risk of coastal erosion in Calabria (Italy): A case study. Ocean and Coastal Management, 132, pp. 24-35, 2016.

[16] Barbaro, G., Foti, G. \& Sicilia, C.L., Coastal erosion in the south of Italy. Disaster Advances, 7, pp. 37-42, 2014.

[17] Foti, G. et al., Shoreline changes near river mouth: case study of Sant'Agata River (Reggio Calabria, Italy). European Journal of Remote Sensing, 52(4), pp. 102-112, 2019.

[18] Canale, C. et al., Analysis of floods and storms: concurrent conditions. Italian Journal of Engineering, Geology and Environment, 1, pp. 23-29, 2020.

[19] Barbaro, G. et al., Mapping of coastal flooding areas. Case studies: Scilla and Monasterace (Italy). International Journal of Safety and Security Engineering, 10(1), pp. 59-67, 2020.

[20] Barbaro, G., Foti, G., Mandaglio, G., Mandaglio, M. \& Sicilia, C.L., Estimate of sediment transport capacity in the basin of the Fiumara Annunziata (RC). Rendiconti Online Società Geologica Italiana, 21(1), pp. 696-697, 2012.

[21] Sicilia, C.L., Foti, G. \& Campolo, A., Protection and management of the Annunziata river mouth area (Italy). Journal of Air, Soil and Water Research, 6, pp. 107-113, 2013.

[22] Barbaro, G. \& Foti, G., Shoreline behind a breakwater for wave energy absorption in Reggio Calabria: comparison between theoretical models and experimental data. WIT Transactions on Ecology and the Environment, vol,. 149, WIT Press: Southampton and Boston, pp. 237-248, 2011.

[23] Barbaro, G., Foti, G. \& Sicilia, C.L., Wave forces on upright breakwater, evaluation and case study. Disaster Advances, 6, pp. 90-95, 2013.

[24] Baratta, M., I Terremoti d'Italia. Saggio di Storia, Geografia e Bibliografia Sismica Italiana, F.lli Bocca, Turin, Italy, 1901. (In Italian.)

[25] Sarconi, M., Istoria de' fenomeni del tremuoto avvenuto nelle Calabrie e nel Valdemone nell'anno 1783, Napoli, 1874. (In Italian.)

[26] Comastri, A. \& Mariotti, D., I terremoti e i maremoti dello Stretto di Messina dal mondo antico alla fine del XX secolo:descrizioni e parametri. Il terremoto e il maremoto del 28 dicembre 1908: analisi sismologica,impatto, prospettive, DPCINGV, Bologna, Roma, 813 pp., 2008. (In Italian.)

[27] Zaniboni, F., Pagnoni, G., Gallotti, G., Paparo, M.A., Armigliato, A. \& Tinti, S., Assessment of the 1783 Scilla landslide-tsunami effects on Calabria and Sicily coasts through numerical modeling. Natural Hazards and Earth System Sciences, 2019.

[28] Foti, G. \& Sicilia, C.L., Analysis, evaluation and innovative methodologies to prevent coastal erosion. WIT Transactions on Ecology and the Environment, vol. 169, WIT Press: Southampton and Boston, pp. 219-230, 2013. 
[29] Barbaro, G., Fiamma, V., Barrile, V., Foti, G. \& Ielo, G., Analysis of the shoreline changes of Reggio Calabria (Italy). International Journal of Civil Engineering and Technology, 8(10), pp. 1777-1791, 2017.

[30] Borrello, M.M., Foti G. \& Puntorieri P., Shoreline evolution near the mouth of the Petrace River (Reggio Calabria, Italy). Proceedings of 9th International Conference on River Basin Management, Prague, Czech Republic. WIT Transactions on Ecology and the Environment, vol. 221, WIT Press: Southampton and Boston, pp. 59-67, 2017.

[31] Barbaro, G., Bombino, G., Foti, G., Borrello, M.M. \& Puntorieri, P., Shoreline evolution near river mouth: Case study of Petrace River (Calabria, Italy). Regional Studies in Marine Science, 29, 100619, 2019.

[32] Versaci, R., Minniti, F., Foti, G., Canale, C. \& Barillà, G.C., River anthropization: Case studies in Reggio Calabria, Italy. WIT Transactions on Ecology and the Environment, vol. 217, WIT Press: Southampton and Boston, pp. 903-912, 2018.

[33] Minasi, G., Continuazione ed appendice sopra i tremuoti descritti nella relazione colla data di Scilla de 30 settembre 1783, con altro che accadde in progresso, Messina, 1785.

[34] Minasi, A., La specola del filosofo, Natura e sorti nelle incisioni di Antonio Minasi, Ilario Principe, "Brutium", 1970.

[35] De Lorenzo, A., Memorie da servire alla storia sacra e civile di Reggio e delle Calabrie, Cronache e Documenti inediti o rari, vol. I, Reggio Calabria, 1877.

[36] Zaniboni, F., Armigliato, A. \& Tinti, S., A numerical investigation of the 1783 landslide-induced catastrophic tsunami in Scilla, Italy. Natural Hazards, 84, pp. 455470, 2016.

[37] Mazzanti, P. \& Bozzano, F., Revisiting the February 6th 1783 Scilla (Calabria, Italy) landslide and tsunami by numerical simulation. Marine Geophysical Research, 32, pp. 273-286, 2011.

[38] Bozzano, F., Lenti, L., Martino, S., Montagna, A. \& Paciello, A., Earthquake triggering of landslides in highly jointed rock masses: Reconstruction of the 1783 Scilla rock avalanche (Italy). Geomorphology, 129, pp. 294-308, 2011. 